\title{
Yemen's Human Rights Abuses Skyrocket Amidst Ongoing Chaos
}

\author{
Shaul M. Gabbay ${ }^{1}$ \\ ${ }^{1}$ Global Research Institute, Denver, CO, United States \\ Correspondence: Shaul M. Gabbay, Global Research Institute, Denver, CO, United States.
}

Received: May 13, 2021

Accepted: June 3, $2021 \quad$ Available online: June 25, 2021

doi:10.11114/ijsss.v9i4.5272

URL: https://doi.org/10.11114/ijsss.v9i4.5272

\begin{abstract}
Six years of war in Yemen have destroyed human rights in a country whose record was already abysmal. Yemen is considered the largest humanitarian crisis in the world, largely due to its food insecurity. Destroyed infrastructure, lack of services and fuel, a non-functioning government, and continued fighting has taken the lives of over 18,000 civilians, leaving survival efforts to take precedent overall. With no oversight, human rights are non-existent. A significant rise in violence has occurred against women including abuse, rape, and torture by a number of parties, including belligerents. Houthi rebels, Saudi forces, and Saudi backed Yemeni forces have all been documented to have committed serious abuses against civilians. For women, violence in the home is even worse. With extremely limited rights and protection, women remain vulnerable to domestic and sexual violence from relatives and have little to no recourse. Honor killings remain acceptable, and young girls are frequently married off as there is no minimum age of marriage. With chaos continuing to block most outside help, Yemeni's will continue to suffer extreme human rights abuses until the war ends.
\end{abstract}

Keywords: Yemen, human rights, women's rights, honor killing, tribal, starvation, Houthi.

\section{Introduction}

\section{Human Rights Plummet in Face of Ongoing War}

Manifold concerns over Yemen have been mounting since the state officially became a republic in 1990. Almost immediately the situation began deteriorating, and four years later separatists tried splitting the country back into north and south regions as it had been prior to the formal unification. This created an unstable situation that has persisted ever since. Add seven year of intense civil war bolstered by foreign armies fighting on Yemeni soil and foreign financial backing of internal militias to existing concerns, and it becomes difficult to choose which disaster to tackle first: rampant starvation described as "the world's worst humanitarian crisis" (Johnson, 2021), or the carpet of landmines and improvised explosive devices (IED's) that create physical, emotional, and economic scars on the civilian population. (Gurley, 2021) Then there is the endlessness of fighting that has destroyed Yemen's infrastructure, economy, health, and sanity, leaving more than half the country living in abject poverty. One thing is for certain in this competing caldron of maladies - human rights are sinking to unimaginable depths. Yemen is a country teetering on the precipice of doom.

\subsection{Tribal Society}

Nearly all of Yemen's most serious challenges are rooted in its deeply tribal society in which four out of five Yemenis identify as "belonging to a tribal group." (ACAPS, 2020) Tribes exert control over geographical areas within Yemen, a control that has grown in the absence of a strong, functioning government. Indeed, it is not incorrect to state that tribes control the country as they are the only social group allowed to bear weapons. This ability to bear arms gives tribes, specifically male tribesmen, the ability "to dominate all aspects of political, economic, and cultural activity in Yemen." (ACAPS, 2020)

Yemen's civil war with its lack of a viable solution, its food and medicine shortages, its unstable and fractured government, and its human rights abuses which this paper addresses, stem in large part from the intrinsic and ancient societal tribal structure that is out of sync with a modern world. Some scholars argue that Westerners overestimate tribal influences in Yemen. (Schmitz, 2011) This is a puzzling stance since tribal leaders hold the reins of power regarding distribution of food and medicine, and nearly entirely control societal power structures including the rights and treatment of women.

The ancient structures of tribes that were once necessary for survival simply do not translate well into a modern state, wherein it is more common to think in terms what is best for the most people. In contrast, "Tribal values hinge entirely 
on the protection of their own tribe. Core humanitarian principles such as impartiality and neutrality are not congruent with tribal traditions." (ACAPS , 2020) For example, the ideas of allowing equitable food and resource distribution among all tribes is an entirely foreign concept. Keeping one's own tribe strong is the sole aim of Yemen's tribal leaders, who are often referred to as shaykhs.

However there are significant differences between tribes and between adherence to tribal power in different areas of the country, and Yemen's tribal system is slowly evolving. That evolution, however, must occur faster or millions of Yemeni's will needlessly suffer and die.

\section{Blocking Humanitarian Aid Access}

\subsection{Prevention of Aid as a Human Rights Abuse}

Specific numbers clarify the ever increasing urgency; fully $80 \%$ of Yemen's people are reliant on humanitarian aid. This insecurity hits children hardest, and 400,000 Yemeni children under five could die of starvation in the coming year alone. UN agencies predict a $22 \%$ rise in "severe, acute malnutrition among children under five." (FAO-WFP, 2021)

Primary and secondary health care has all but ceased to exist in Yemen. Diphtheria and dengue fever are prevalent, and cholera is rampant. Maternal health is practically non-existent, and nursing mothers with malnutrition cannot provide any or enough milk for their newborn infants, all of which results in a high under-five mortality rate. (UNICEF, 2020)

Poverty, hunger, malnutrition, starvation, and a dearth of medical care are human rights abuses in Yemen in that they exist not as a result of a natural disasters, but due to fighting over dominion, politics, and control of resources. There is not a shortage of food, water, or medicine to be had. Rather, there is a shortage of access. Access that could be granted.

Over the years aid organizations have been moored off the coast of Yemen for months at a time trying desperately to provide food and medicine to suffering Yemenis. With few cessations in bombings and other attacks, agencies are rarely able to deliver life-saving supplies. Other times, tribal leaders are using control of food as a war tactic.

A striking example of this tactic occurred in the northern part of the country governed by Houthi Rebels funded by Iran when they threatened to place a tax on all foreign aid; it ended with disastrous results. The United States immediately suspended $\$ 73$ million of its aid program to Yemen, and multiple aid agencies did as well. These actions have further spiked the world's largest humanitarian disaster.

\subsection{Pandemic as a Multiplier}

Amidst all this trauma, the deadly Covid pandemic descended on a malnourished population with very low immunity to disease. While the virus in Yemen was a natural occurrence, treatment was not forthcoming in many areas. Tribal leaders' denial that the pandemic was real, or present, complicated treatment, and many Yemenis who could have been saved died at home. (al-Maghafi, 2021) The impact of the US aid suspension and that of other countries and organizations on Covid treatments was enormous. Patients died from a lack of oxygen tanks, protective gear was largely non-existent, and doctors' pay - already exceedingly low—was cut all together, largely due to financial constraints and related cutbacks by the World Health Organization. With no protective gear and no pay, some doctors quit coming to work. Others carried on bravely, incurring personal debt. Meanwhile, fighters on the front lines continued to be paid. (al-Maghafi, 2021)

Saudi Arabia not only continued its airstrikes on Yemen during the first year of the pandemic, it doubled the number of strikes to take advantage of a weak and dying populace.

The ongoing war is at the root of all nearly all Yemeni suffering. Because the fighting is preventable, it is also a massive human rights abuse. As one Yemeni nurse opined: "A virus comes from God or from nature and the whole world is in an uproar as if the world is going to end. All these countries, desperate to find a vaccine. Can't they find a vaccine that will end this war of ours?" (al-Maghafi, 2021).

\section{The Challenge of Being Female in Yemen}

\subsection{Battle for Equal Rights}

Long considered second class citizens in Yemen, women here have long struggled with their low status and lack of rights. While other Middle East and North African countries have progressed in this area, Yemen's progress is painfully slow, and hard fought gains are frequently reversed. In 2011, Yemeni women shocked their fellow citizens by participating boldly in Yemen's version of the Arab revolution. While a small percentage of Yemeni women had begun fighting for their civil rights even before 2011, their participation in the Arab Spring uprising of 2011 was significant, exceeding the role of women in other countries like Egypt and Tunisia who had been considered far more liberal. Nevertheless, Yemeni women paid dearly for their bravery.

During those 2011 protests in which they marched side-by-side with men, women were brutally attacked, insulted, 
beaten, and kidnapped. In some areas women were injured and killed for protesting. (Yemen Organization for Defending Rights and Democratic Freedoms, 2013) Despite this oppression Yemeni women remained stalwart, demanding and winning a thirty percent quota of seats in the National Dialogue Conference.

Hopes were high as the National Dialogue was tasked with drafting a new constitution, and women expected to make a giant step toward equal citizenship and greater political representation. It took four years, until 2015, for the committee to draft the new constitution that would grant women significant provisions for equal rights in Yemen. However, several groups refused to vote on the changes, and soon after the war broke out. No progress was made, and for women, conditions quicky reverted to pre-uprising standards. As government strength has continued to fragment and weaken, and tribal strength has increased, women's rights have further deteriorated to horrific levels.

\subsection{Value of a Woman's Life}

Yemeni women's multiple societal inequities stem from one central premise, which is the tribal-based belief that the life of a man holds greater value than that of a woman's. This core belief leads to a loss of choice for most women in nearly every area of their lives. Most girls and women are not free to choose their own husband, nor choose when they will marry. Many girls are forced to marry when they are still children, some as young as eight years old. (Amnesty International, 2009)

The family motives for arranging marriages for young daughters are multiple. Two reasons lead the list: reducing the girls financial load on poor families and marrying off daughters before they have a chance to become impure, thereby safeguarding the family's honor.

Portions of the Yemeni constitution clearly dictate the discrimination of women, such as Article 42 of the Crimes and Punishment Law Number 12 which deems the value of a man's life to be double that of a woman's life. This is applied in cases such as the incident of an unintended killing, where Yemeni law identifies compensation for killing a male to be double the amount for female victims' families, effectively devaluing the female's life to half as much as a man's." (Mohsen, 2019) Similarly, women's testimonies in court are valued at one-half of a man's testimony. They are further denied equal treatment in the case of inheritance, for which they are frequently denied entirely. (Amnesty International, 2009)

While the situation for Yemeni women appears intolerable to much of the world, in Yemen it is obvious why it remains unchanged, as over $90 \%$ of members of the House of Representatives are tribal chiefs. Juridical protection is insufficient in the hands of these patriarchal overseers of Yemen's cultural and political structures.

\subsection{Violence Against Women}

Few laws exist to protect women and society commonly violates laws that do, so it is not surprising to find extreme levels of violence against women common across Yemen. The war has dramatically exacerbated the extent of that use of brutality. As the economy plunged throughout the war and unemployment rose, men took out their anger and frustration on the women in their lives. Physical and verbal abuse became increasingly widespread. Local social service agencies reported a ten-fold increase in domestic violence over the course of the war thus far, and that violence "often results in murder." (Yemeni Women's Union, 2019)

Amidst this violence against women and girls, however, one crime stands alone as the most intrinsic and difficult to control or punish - the outright killing of wives, sisters, daughters, and even mothers in an effort to restore family and tribal honor after the "shame" these women are said to have brought on with their actions. While this tradition is ancient and continues to be accepted in scores of countries around the world, particularly in countries where traditional, tribal, mores linger, Yemen is exceptional in that honor killings occur with near-impunity. A large proportion of crimes committed against women who are murdered are not recorded, and thus the number of honor killings are not known.

While these implications resulting from such a group-mindset that diminishes women are incalculable and permeate Yemeni society in literally every dimension, including employment, freedom of movement, dress restrictions, and multiple other arenas, there is no area as discriminatory, as dangerous, and as outright deadly for women as the practice of honor killing that runs rampant in Yemen.

\subsection{Honor Killing}

The war has dramatically exacerbated the use of brutality. As the economy plunged throughout the war and unemployment rose, men took out their anger and frustration on the women in their lives. Physical and verbal abuse became increasingly widespread. Local social service agencies reported a ten-fold increase in domestic violence over the course of the war thus far, and that violence "often results in murder." (Yemeni Women's Union, 2019)

Amidst this violence against women and girls, however, one crime stands alone as the most intrinsic and difficult to control or punish - the outright killing of wives, sisters, daughters, and even mothers in an effort to restore family and 
tribal honor after the "shame" these women are thought to have brought on with their actions.

Honor killing can be defined as "the traditional practice of killing a family member who is believed to have brought shame on the family." Since Yemeni women are nearly always viewed as a source of shame, (Mohsen, 2019), the crime is entirely directed at women. This occurs most often when a woman is thought to be having some kind of personal relationship with a man outside of marriage. The shame on the family or tribe is so intense, however, that a mere suspicion of such activity provides enough reason to murder a family member.

An example speaks volumes. One twelve-year old girl was suspected by her father of committing adultery. He actually filmed her slow torture as he questioned her repeatedly. She continued to deny the action, which coincided with the three reports he had already received from three separate doctors verifying her virginity. After undergoing extreme torture she finally said that she was guilty, after which he electrocuted her.

One might suspect that such barbarism would be punished by state actors. However, Article 59 of the Yemeni penal code states "There is no retribution for a branch (son or daughter) killed by an origin (father or grandfather), only blood money or indemnity may be paid, according to circumstance," giving a father free rein to kill his daughter in impunity. (Mohsen, 2019).

Women are part of the problem, too, either aiding and abetting or killing their daughters or daughters-in-laws outright to restore honor to their families. One such instance came as a convenience rather than a true honor killing, when a mother smuggled a knife into a courtroom and handed it to her son who, in front of the judge and everyone else, stabbed his sister in the neck and killed her. The sister had not brought shame, but she and her two children were becoming a burden for the family. Even though the judge bore witness to the crime and issued a death penalty to the slain woman's brother, the father was allowed to appeal the verdict on the grounds of an honor killing.

\subsection{Dearth of Prosecution Encourages Violence}

These brutal and violent crimes against women in Yemen can only occur in the absence of prosecution. Since severe penalties are doled out to those who commit similar crimes against males, there exists an implicit approval to harm women. A researcher at one human rights organization summed up the situation this way: "That Yemeni law is inadequate when it comes to dealing with "honor killings - it does not contain deterrent and heavy penalties to punish the perpetrators. On the contrary, Yemeni law currently facilities impunity." (Euro-Mediterranean Human Rights Monitor, 2020)

\section{Discussion}

While Yemen is an independent country, it's treatment of women is wholly unacceptable. Nations have a responsibility to hold Yemeni leadership accountable by using a series of carrots and sticks. Countries who have been fighting a proxy war in Yemen have an even greater responsibility, but they themselves have terrible human rights records particularly around the treatment of women. Saudi Arabia, Iran, and to a lesser degree, United Arab Emirates, all have abysmal records, and the West cannot expect any positive influence from these actors. The United States on the other hand has provided Saudi Arabia with weapons to fight in Yemen for several years, finally ending the largesse in 2021. Nevertheless, the United States still has a hand in Yemen, and could bring pressure to bear on both Saudi Arabia and the United Arab Emirates and can influence their allies in Yemen on treatment of women and other human rights issues.

The unparalleled human disaster unfolding in Yemen due to starvation will always loom larger than human rights and women's rights issues. One must prioritize to first sustain life, and then put efforts on protecting rights. This doesn't work however, when a country exists in continual crisis. There is unlikely to be a time in the foreseeable future when survival does not top Yemen's tower of concerns. Therefore, the United States and other countries concerned for the welfare of women and girls must make some demands of Yemen in return for assistance of any kind. Tying improved human rights to aid or any benefits is a balancing act, but one that can be achieved and at the very least, attempted. At this point there are no efforts to do so, and the US and other concerned nations can do more to drive change.

Leaders inside Yemen hold the keys to creating and sustaining real change, however. The Yemeni parliament must create legislation to provide protection to all those suffering from human rights abuses in the country. Since women make up half the population, directing sufficient effort to create laws guaranteeing special protection of women consistent with international standards as set forth in the Universal Declaration of Human Rights is an essential, first step.

Further, it is clear that tribal beliefs hold undue influence in the Yemeni parliament, and those antiquated viewpoints must be purged by reforming the legislative system. As long as $90 \%$ of legislators claim adherence to a tribal affiliation and remain tied to those beliefs, change cannot take place.

Yemeni women must be empowered to represent themselves. Their voices must be heard and considered. Until women hold equal representation in government, they will continue to be discriminated and abused as they are today. 


\section{References}

ACAPS. Tribes in Yemen: An Introduction to the Tribal System. Geneva: ACAPS Yemen Analysis Hub, 2020.

Amnesty International. Yemen's Dark Side: Discrimination and Violence Against Women and Girls. 25 November 2009. Retrieved from https://reliefweb.int/sites/reliefweb.int/files/resources/26C10FFED5BB0358492576C00025E55F-Full_Report.pdf

Euro-Mediterranean Human Rights Monitor. Girl Killed in Yemen in Shocking Circumstances: Perpetrators Must be Held Accountable. Euromediterranean Human Rights Monitor. 19 March 2020. Retrieved from https://euromedmonitor.org/en/article/3427/Girl-killed-in-Yemen-in-shocking-circumstances:-Perpetrators-must-be -held-accountable

FAO-WFO. Hunger Hotspots: FAO-WFP Early Warnings on Acute Food Insecurity. Rome. Food and Agriculture Organization of the United Nations and World Food Program, 2021.

Gurley, Daniel. Small Steps Have a Big Impact for Yemeni Civilians. US State Department. 6 April 2021. Retrieved from https://www.state.gov/dipnote-u-s-department-of-state-official-blog/small-steps-have-a-big-impact-for-yemeni-civi lians/

Johnson, Gregory D. Order from Chaos: The End of Yemen. Brookings Institute. 25 March 2021. Retrieved from https://www.brookings.edu/blog/order-from-chaos/2021/03/25/the-end-of-yemen/

Mohsen, Abeer. "Honour" Killings in Yemen: Tribal Tradition and the Law. Daraj.19 December 2019. Retrieved from https://daraj.com/en/36602/

Nawal al-Maghafi (Director). Yemen's Covid Cover-Up. [Television series episode.] Frontline. Sara Obeidat, Producer. 2021. Public Broadcasting Corporation.

Schmitz, Charles. "Understanding the Role of Tribes in Yemen.” CTC Sentinel October 2011.

UNICEF. Country Profiles: Yemen. 2020. 2020. Retrieved from https://data.unicef.org/country/yem/

Yemen Organization for Defending Rights and Democratic Freedoms. Women's Rights in Yemen: Joint NGO Stakeholder Report." UN Office of the High Commissioner for Human Rights (2013).

Yemeni Women's Union. Yemen Women Union. October 2019. Retrieved from http://yemenwu.org/en/

\section{Copyrights}

Copyright for this article is retained by the author(s), with first publication rights granted to the journal.

This is an open-access article distributed under the terms and conditions of the Creative Commons Attribution license which permits unrestricted use, distribution, and reproduction in any medium, provided the original work is properly cited. 